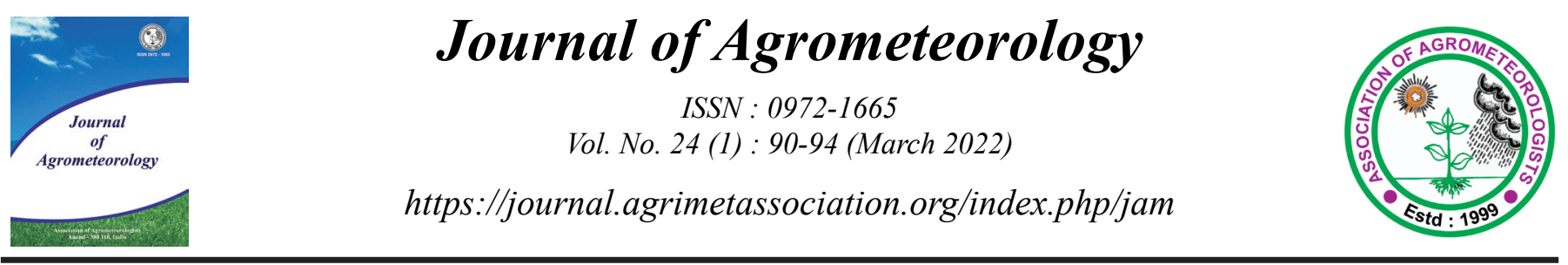

Short Communication

\title{
Delineation of thermal requirements of rice (Oryza sativa L ) using geospatial technology in Punjab
}

\author{
UPASANA MANHAS ${ }^{1}$, SOM PAL SINGH ${ }^{*}$, P.K. KINGRA ${ }^{1}$, R. K. SETIA ${ }^{2}$ and RAJNI SHARMA ${ }^{3}$
}

${ }^{1}$ Dept of Climate Change \& Agricultural Meteorology, PAU, Ludhiana, India

${ }^{2}$ Punjab Remote Sensing Centre, Ludhiana, India

${ }^{3}$ Dept of Agronomy, PAU, Ludhiana, India

*Corresponding author email : sompal69@pau.edu

Agriculture is the backbone of our country consisting of $70 \%$ of rural households and root of our civilization. About $52 \%$ of the total number of jobs in India are provided by the agriculture sector. The contribution of agriculture to the total GDP is around 17\% (Arjun, 2013). The main determinant of agricultural production is climate. On global scale, both climate change and agriculture are interrelated processes. The recent reports indicated the remarkable increase in the temperature at global and regional scale. As projected by global circulation models, the temperature increase of 1.1 to $6.4^{\circ} \mathrm{C}$ (Pachauri and Reisinger, 2007) will reduce the duration of rice ranging from 9 to 14 days by the end of the century (Ramaraj and Jagannathan, 2013). A study revealed that there is increase in temperature from north-east to south-western region of Punjab (Kingra et al., 2017). This is driving force for the crop production as the increase in the temperature fastens the physiological processes, which in other way affect the heat unit requirements of the rice. This alarming situation demands for analyses of the spatio-temporal variability in climatic patterns at regional scale in order to adopt mitigation strategies on regional basis.

Growing degree days (GDD) is a simple temperaturebased index of biological development (Hassan et al., 2007) based on the concept that there is linear relationship between right time for attainment of certain phenological stages and the difference between mean and base temperature. Under field conditions, temperature influence on development and yield of crop plants is studied through accumulated heat unit system as plants have a distinct temperature requirement prior to the attainment of certain phenological stage. A study was therefore planned to find out the heat unit variability in rice due to climate change on Spatio-temporal scale usingArc GIS 10.2 .
Long term (1990-2019) district-wise climate data (maximum and minimum temperature) during the rice growing season (June to October) was collected from Department of Climate Change and Agricultural Meteorology, Punjab Agricultural University (PAU) Ludhiana, India Meteorological Department and different websites. Long-term growing degree days were computed for rice under three transplanting windows viz. $13^{\text {th }}$ June (window-I), $21^{\text {st }}$ June (window -II) and $29^{\text {th }}$ June (windows-III). Spatial interpolation of rice accumulated growing degree days was done using Inverse Distance Weighted (IDW) method in ArcGIS 10.2 by taking average of pentads from 1990 to 2019 .

Variability in thermal requirements of rice in transplanting window I

In the North east region of Punjab during the period from 1990-1994 to 2010-2014 AGDD were found to shift from 1900-2100 ${ }^{\circ} \mathrm{C}$ day to $2100-2300{ }^{\circ} \mathrm{C}$ day in Gurdaspur and Hoshiarpur district. In S.B.S. Nagar, major portion was under $1700-1900^{\circ} \mathrm{C}$ day which changed to $2300-2500{ }^{\circ} \mathrm{C}$ day in 2010-2014. In Rupnagar AGDD changed from $1900-2100{ }^{\circ} \mathrm{C}$ day to $2300-2500{ }^{\circ} \mathrm{C}$ day. In the central region of Punjab the major portion of Amritsar was under 2100-2300 ${ }^{\circ} \mathrm{C}$ day in 1990-1994. In 2010-2014 the whole district was under 2100-2300 ${ }^{\circ} \mathrm{C}$ day. Whereas, in Moga and Sangrur AGDD shifted from $2100-2300$ day to $2300-2500{ }^{\circ} \mathrm{C}$ day. During the same time period in major portion of Ludhiana, Patiala, Kapurthala, Jalandhar and Fatehgarh Sahib AGDD changed from 1900-2100 to 2100$2300^{\circ} \mathrm{C}$ day. In the South West region mainly in Faridkot, Firozpur, Mansa, Muktsar and Bathinda, they were found to change from $2100-2300^{\circ} \mathrm{C}$ day to $2300-2500^{\circ} \mathrm{C}$ day during same time period. During the period from 2015-2019 AGDD value in whole state came under the range of $2300-2500^{\circ} \mathrm{C}$ day except Ludhiana and

Article info - DOI: https://doi.org/10.54386/jam.v24i1.903

Received: 25 February 2021; Accepted: 29 December 2021; Published online: 11 February 2022

This work is licenced under a Creative Common Attribution4.0International licence@Author(s),Publishing right@ Association of Agrometeorologists 

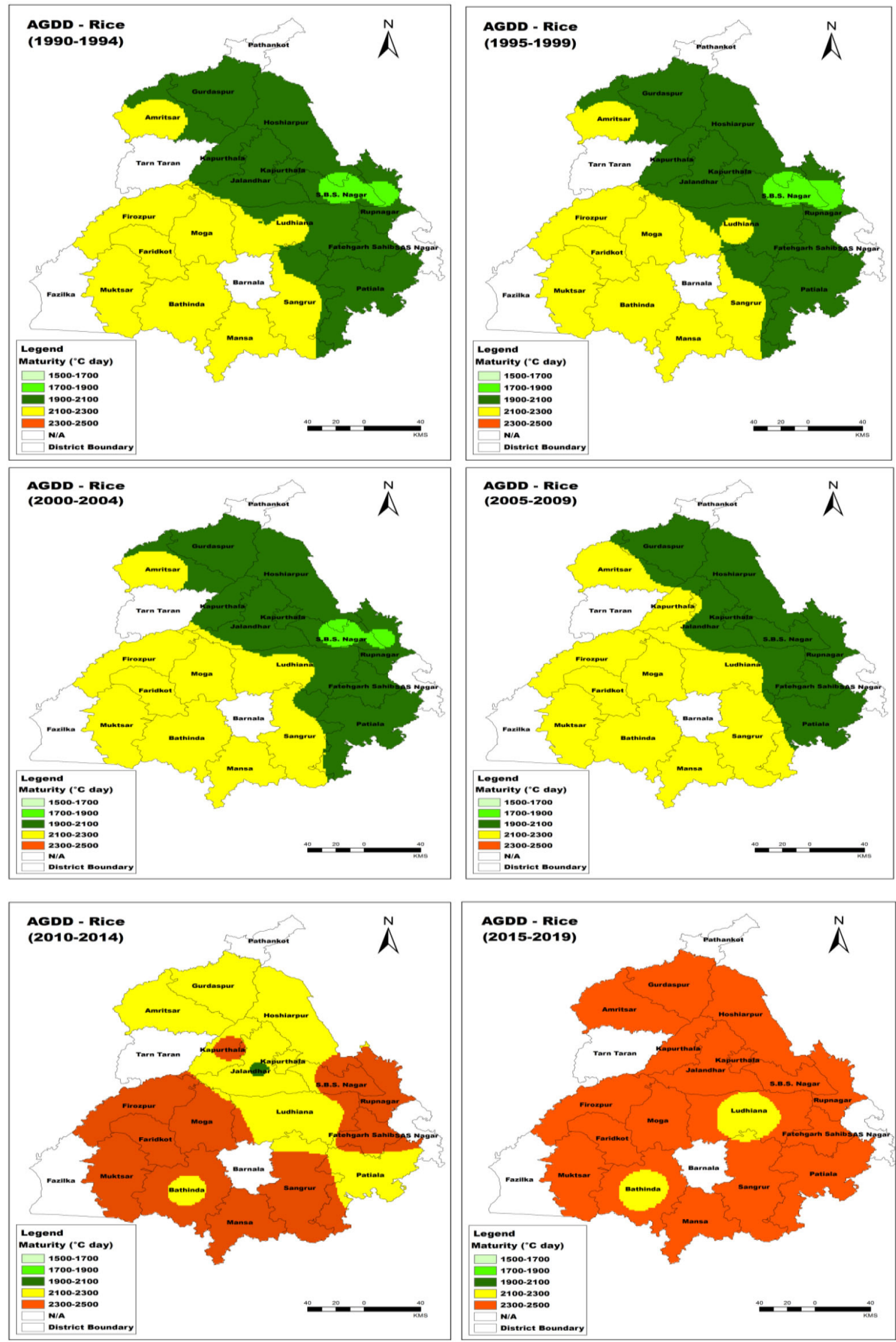

Fig. 1: Spatio-temporal variability in AGDD of rice for different pentads during 1990 to 2019 in Punjab for transplanting window I 

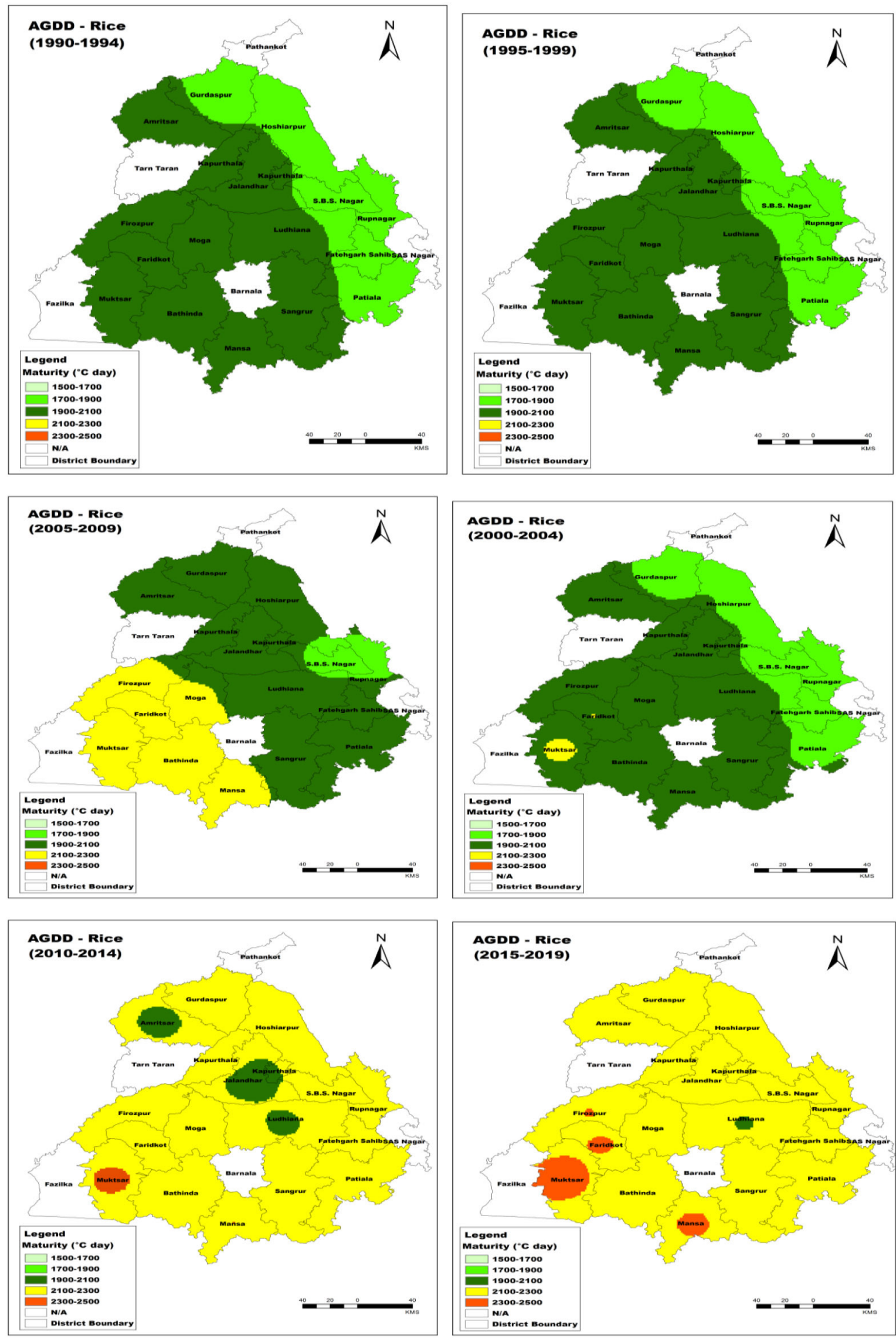

Fig. 2: Spatio-temporal variability in AGDD of rice for different pentads during 1990 to 2019 in Punjab for transplanting window II 

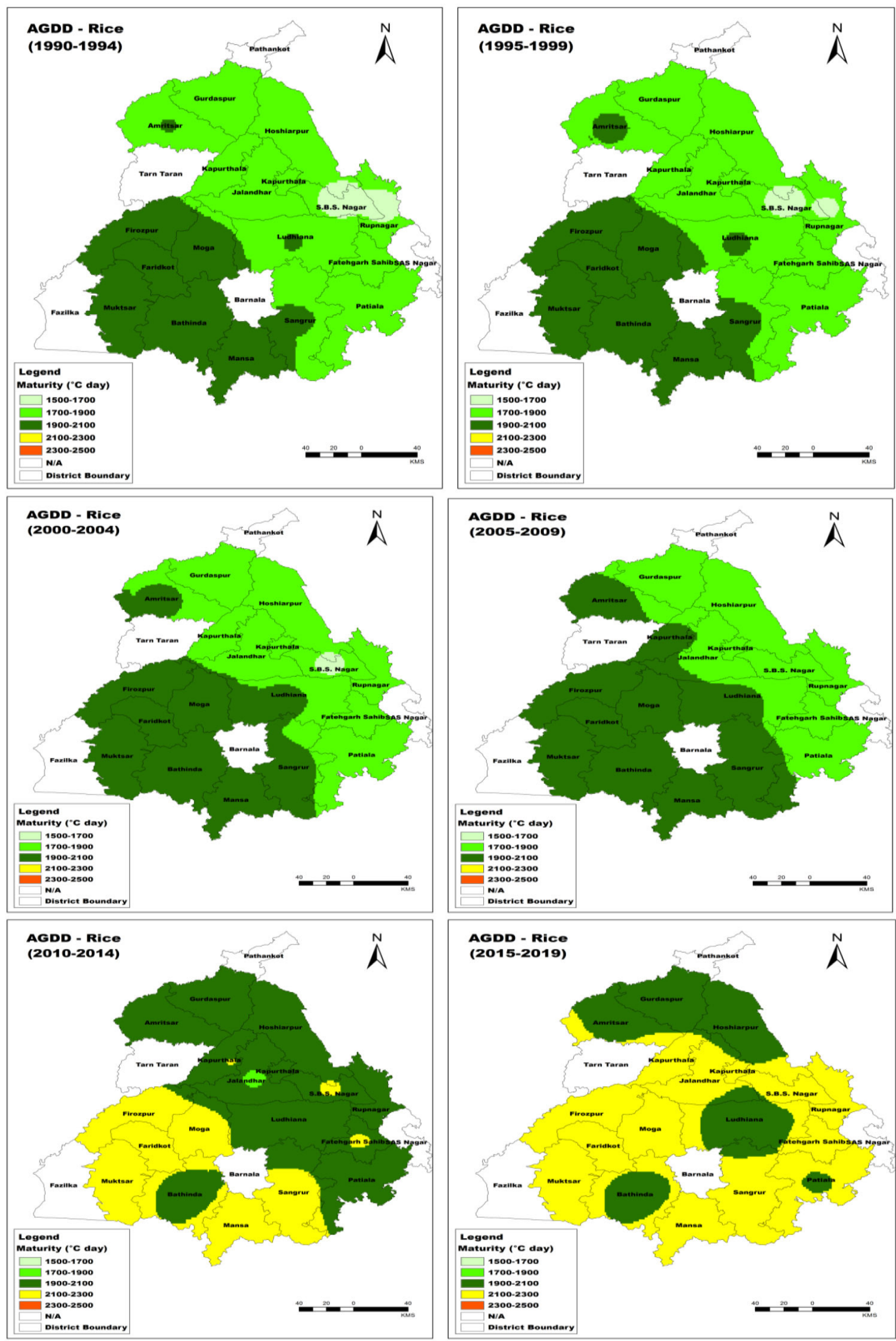

Fig. 3: Spatio-temporal variability in AGDD of rice for different pentads during 1990 to 2019 in Punjab under transplanting window III 
Bathinda (2100-2300 ${ }^{\circ} \mathrm{C}$ day). (Fig 1). Mohapatra et al (2021) also studied the effect of different sowing dates on AGDD requirements of the rice, which corroborates the present investigation.

\section{Variability in thermal requirements of rice in transplanting window II}

In the north east districts during 1990-1994 to 2015-2019 the AGDD were reported to shift from $1700-1900{ }^{\circ} \mathrm{C}$ day to 2100 $2300{ }^{\circ} \mathrm{C}$ day. In central region during same time period AGDD changed from $1900-2100$ to $2100-2300{ }^{\circ} \mathrm{C}$ day in Amritsar, major portion of Ludhiana, Kapurthala, Jalandhar, Moga and Sangrur. The AGDD in district Fatehgarh Sahib and Patiala shifted from 1700$1900{ }^{\circ} \mathrm{C}$ day to $2100-2300{ }^{\circ} \mathrm{C}$ day. In south-west districts, these were changed from $1900-2100$ to $2100-2300{ }^{\circ} \mathrm{C}$ day during pentad of 1990-1994 to 2015-2019 except in some portion of Mansa, Muktsar and Faridkot where it changed to $2300-2500{ }^{\circ} \mathrm{C}$ day. (Fig. 2).

\section{Variability in thermal requirements of rice in transplanting window III}

Under transplanting window III, from 1990-1994 to 20102014 in the north east districts, Gurdaspur and Hoshiarpur, and major portion Rupnagar AGDD changed from $1700-1900{ }^{\circ} \mathrm{C}$ day to $1900-$ $2100^{\circ} \mathrm{C}$ day. However, in major portion of S.B.S. Nagar the heat unit accumulation changed from $1500-1900^{\circ} \mathrm{C}$ day to $1900-2100^{\circ} \mathrm{C}$ day. In central region, during the same period AGDD shift from 1700$1900{ }^{\circ} \mathrm{C}$ day to $1900-2100{ }^{\circ} \mathrm{C}$ day in Amritsar, Kapurthala, Jalandhar, Ludhiana, Fatehgarh Sahib and Patiala. However, in Moga AGDD vary from $1900-2100$ to $2100-2300^{\circ} \mathrm{C}$ day and in major portion of Sangrur, the AGDD vary from 1700-1900 to 2100-2300. The South west region, in all districts AGDD vary from 1900-2100 to 2100$2300{ }^{\circ} \mathrm{C}$ day except in Bathinda where AGDD remain 1900-2100 ${ }^{\circ} \mathrm{C}$ day. During 2015-2019 period in whole north-east, central and south-west districts, AGDD changed to $2100-2300{ }^{\circ} \mathrm{C}$ day except in Ludhiana, Bathinda, Amritsar, Gurdaspur and Hoshiarpur where AGDD remained $1900-2100{ }^{\circ} \mathrm{C}$ day (Fig.3).

It has been concluded form the study that growing degree days accumulation depicted a shift during the period of 1990 to 2019 due to rise in the temperature. Maximum accumulation of heat units were reported in first transplanting window followed by second and third. The changes in AGDD in different sowing windows will attract the alteration in the phenological events and thereby the growth and maturity of the crops along with their relations with the yields. So it is suggested to pin point the hot spot areas so that location specific strategies may be drawn like the developing varieties which are temperature hardy and adopting suitable transplanting windows and technological innovations to increase the yield of the crops.

Conflict of Interest Statement: The author(s) declare(s) that there is no conflict of interest.

Disclaimer: The contents, opinions and views expressed in the research article published in Journal of Agrometeorology are the views of the authors and do not necessarily reflect the views of the organizations they belong to.

Publisher's Note: The periodical remains neutral with regard to jurisdictional claims in published maps and institutional affiliations.

\section{REFERENCES}

Arjun, K. M. (2013). Indian agriculture-status, importance and role in Indian economy. Int. J. Agric. Food Sci. Tech., 4(4):343-46.

Hassan, Q. K., Bourque, C. P., Meng, F. R. and Richards, W. (2007). Spatial mapping of growing degree days: an application of MODIS based surface temperature and enhanced vegetation index. J. Appl. Remote Sens., 1(1): 140-44.

Kingra, P. K., Setia, R., Singh, S., Kaur, J., Kaur, S., Singh, S., Kukal, S. S. and Pateriya, B. (2017). Climatic variability and its characterisation over Punjab, India. J. Agrometeorol., 19 (3):246-50.

Mohapatra, S.,Tripathy, S. K. , Mohanty, A. K. and Tripathy, S. (2021). Effect of heat stress on yield and economics of rice (Oryza sativa L.) cultivars under different sowing dates. J. Agrometeorol., 23(1):38-45.

Pachauri, R. K. and Reisinger, A. (2007). Climate change and its impacts in the near and long term under different scenarios, Climate Change 2007: Synthesis Report. pp 43-54. IPCC, Geneva, Switzerland.

Ramaraj, A. P. and Jagannathan, R. (2013). Climate change and rice crop duration. J. Agrometeorol., 15: 189-91. 